BMC

Evolutionary Biology

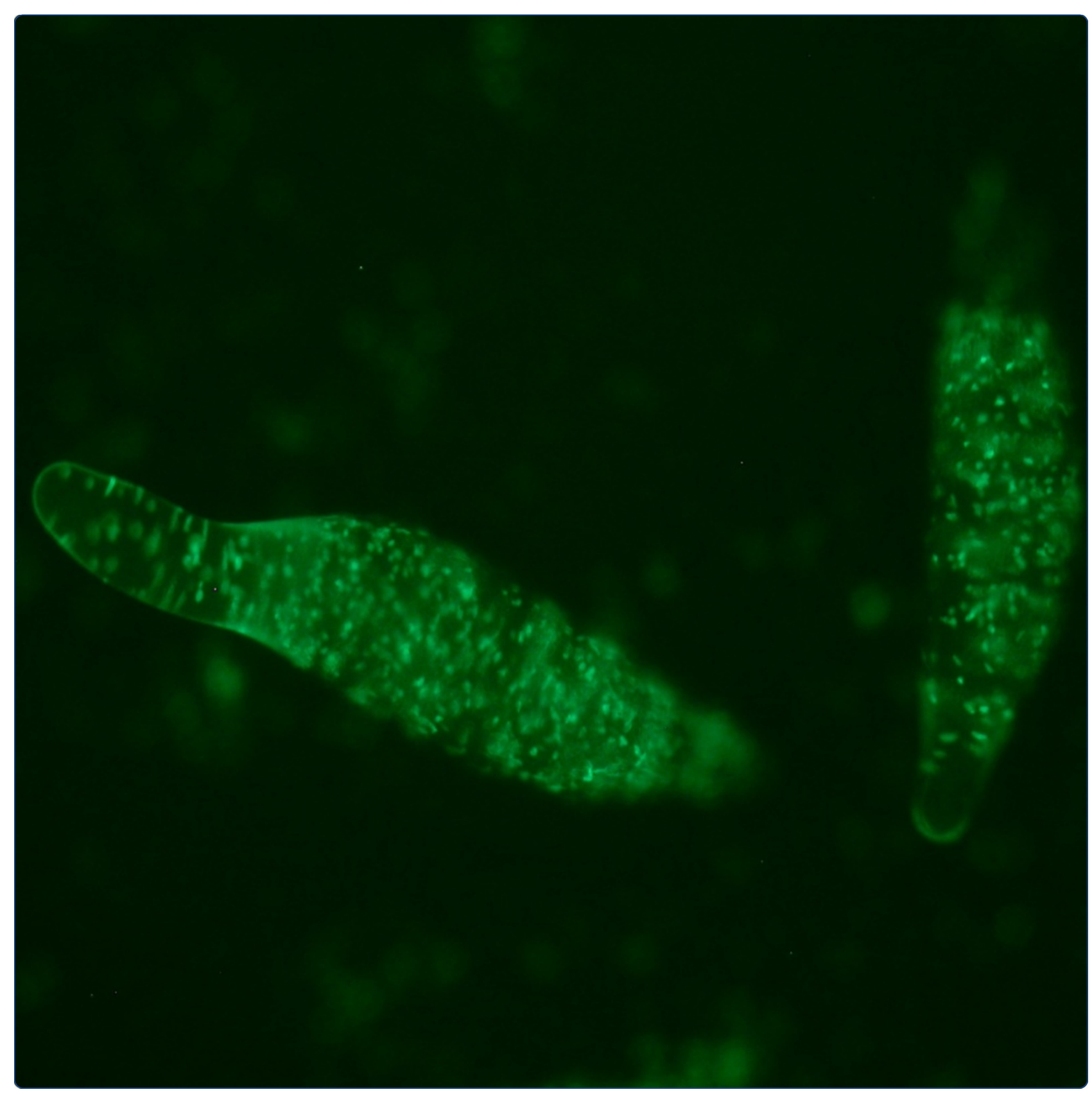

A new social gene in Dictyostelium discoideum, chtB Santorelli et al. 


\title{
A new social gene in Dictyostelium discoideum, chtB
}

\author{
Lorenzo A Santorelli, ${ }^{1,2,5^{*}}$, Adam Kuspa ${ }^{1,2,3}$, Gad Shaulsky ${ }^{1,2}$, David C Queller ${ }^{4}$ and Joan E Strassmann ${ }^{4}$
}

\begin{abstract}
Background: Competitive social interactions are ubiquitous in nature, but their genetic basis is difficult to determine. Much can be learned from single gene knockouts in a eukaryote microbe. The mutants can be competed with the parent to discern the social impact of that specific gene. Dictyostelium discoideum is a social amoeba that exhibits cooperative behavior in the construction of a multicellular fruiting body. It is a good model organism to study the genetic basis of cooperation since it has a sequenced genome and it is amenable to genetic manipulation. When two strains of $D$. discoideum are mixed, a cheater strain can exploit its social partner by differentiating more spore than its fair share relative to stalk cells. Cheater strains can be generated in the lab or found in the wild and genetic analyses have shown that cheating behavior can be achieved through many pathways.

Results: We have characterized the knockout mutant $c h t B$, which was isolated from a screen for cheater mutants that were also able to form normal fruiting bodies on their own. When mixed in equal proportions with parental strain cells, chtB mutants contributed almost $60 \%$ of the total number of spores. To do so, chtB cells inhibit wild type cells from becoming spores, as indicated by counts and by the wild type cells' reduced expression of the prespore gene, cotB. We found no obvious fitness costs (morphology, doubling time in liquid medium, spore production, and germination efficiency) associated with the cheating ability of the chtB knockout.

Conclusions: In this study we describe a new gene in $D$. discoideum, chtB, which when knocked out inhibits the parental strain from producing spores. Moreover, under lab conditions, we did not detect any fitness costs associated with this behavior.
\end{abstract}

Keywords: Cheating behavior, Social evolution, D. discoideum, Pre-spore marker, chtB

\section{Background}

Microorganisms are able to communicate and cooperate to perform complex social behaviors once believed to be distinctive of multicellular organisms [1-5]. This includes formation of biofilms, foraging, spore dispersal and production of common goods. Cooperative groups are vulnerable to exploitation by cheaters, individuals that benefit from the product of cooperation without contributing their fair share [5-9]. In Pseudomonas aeruginosa [10] and Myxococcus xanthus [11,12], for example, the release of siderophores and digestive enzymes, respectively, represent costly activities that could be exploited by nonproducers. In both organisms, strains grown in liquid

\footnotetext{
* Correspondence: lorenzo.santorelli@zoo.ox.ac.uk

${ }^{1}$ Department of Ecology and Evolutionary Biology, Rice University, Houston, TX 77005, USA

${ }^{2}$ Department of Molecular and Human Genetics, Baylor College of Medicine, Houston, TX 77030, USA

Full list of author information is available at the end of the article
}

culture for a number of generations sometime evolve to lose the ability to cooperate and instead behave as cheaters.

Dictyostelium discoideum displays cooperative behavior that provides a great model for the study of cheating. $D$. discoideum propagates as free-living unicellular amoebae feeding on bacteria associated with leaf litter, soil, and animal dung. In the past few decades, this social amoeba has been intensively studied because of its extraordinary development [13], which is a form of cooperation. When starving, cells aggregate and eventually form a multicellular organism capable of movement towards light and heat and away from chemicals such as ammonia [14,15]. Under the correct conditions, they develop into a fruiting body that represents the final stage of development [16]. About $20 \%$ of the cells differentiate into dead stalk cells that support the other $80 \%$, which differentiate into viable spores. When spores are dispersed to a new source of food, they germinate to become amoebae and restart the vegetative
C Biomed Central

(c) 2013 Santorelli et al.; licensee BioMed Central Ltd. This is an Open Access article distributed under the terms of the Creative Commons Attribution License (http://creativecommons.org/licenses/by/2.0), which permits unrestricted use, distribution, and reproduction in any medium, provided the original work is properly cited. 
stage of eating and dividing by binary fission. Stalk cells have been described as altruistic, since their death is presumed to aid the dispersal of the spores that form the next generation [17]. If the population consists of cells that are genetically identical, or related, it is possible to compare these individuals to somatic cells in a multicellular organism, or to a social insect colony. But when cells are genetically different, a conflict may arise over which cells survive and which form the stalk and die. In this case, a strain that differentiates more than its proportional share of spores is called a cheater and the other is called a loser.

In several cases, reproductive competition among cells within a chimera has been reported, but the cheater strains often carry a fitness cost relative to non-cheaters even to the extent that they are incapable of sporulating efficiently on their own [18-20]. On the other hand, in $D$. discoideum several strains isolated from the wild are capable of cheating and of producing fruiting bodies independent of other clones [17]. A large number of knockout or reduced function mutations generated in the laboratory also show such facultative cheating behavior [21]. These mutants are capable of producing spores in pure populations, but preferentially become spores and not stalk cells when mixed with the ancestral strain.

In $D$. discoideum, many genes have been reported to be involved in the disruption of cooperation, but not much is known about the underlying genetic mechanisms. The analyses performed so far on cheater mutants showed that multiple mechanisms and pathways may be involved in cheating behavior, with cheater mutants showing diverse functions including GTPase regulatory activity, polyketide synthesis, nucleotide binding, and phosphoric ester hydrolase activity [21]. Some of these pathways are involved in cell-cell communication, formation of secondary metabolites, or signal transduction. They can affect the communication pathway that regulates the proportion of spores and stalk cells [22], or disrupt the ubiquitin-ligase pathway responsible for the breakdown of certain target proteins [19]. Other mechanisms that can lead to cheating [23] might be the expression of spore genes earlier than prestalk genes [24]; premature entrance into development; presence of multinucleated cells that lead to more cell divisions during development; cannibalism, as is present in Dictyostelium caveatum [25]; and production of a killer factor as reported in Polysphondylium pallidum [26].

Cheater strains in the Dictyostelidae typically have a fitness cost or some deleterious pleiotropic effect that prevents the mutant from spreading, since otherwise a loss of function mutant would easily evolve. This is the case of mutants $\operatorname{cht} A, \operatorname{dim} A$, and $\operatorname{csa} A[19,27,28]$. In this work we characterize a mutant called $\operatorname{cht} B$ that can facultatively cheat when mixed with the parental strain, but does not suffer from an obvious fitness cost in the laboratory. When mixed with $\operatorname{cht} B$, the parental strain produces fewer spores and expresses a lower level of the pre-spore gene $\cot B$.

\section{Results}

A mutant called $\operatorname{cht} B$ (cheater $\underline{B}$ ) was recovered at the end of a selection for mutants that preferentially produce spores rather than stalks in a mixed population [21].

In the parental strain AX4, the chtB transcript appears early in development and is completely absent in chtB mutant cells. This mutant produces a higher number of spores than AX4 in chimeras that are made with equal numbers of cells of the two strains. When it is plated clonally it shows a normal developmental phenotype, so it is not dependent on parental cells in a social stage chimera. The loss of function of the chtB gene also increases expression of $\cot B$, a prespore marker, early in development, indicating the mechanism of action is early specialization as spore over the ancestral strain. On the other hand, parental cells reduce the expression of $\cot B$ and differentiate a lower number of spores in chimera. We tested chtB mutants to detect whether fitness costs were associated with its cheating ability. Not only did we not detect any fitness cost, but we also found that the mutant presents the same sporulation efficiency and faster doubling time when grown in liquid, than AX4. Finally, the presence of chtB mutant cells in chimera with parental strain limits the expression of a pre-spore marker in the latter. As a consequence the parental strain is unable to produce its fair share of spores.

\section{Isolation of the cht $B$ mutants}

We isolated the $\operatorname{ch} t B$ mutant during a selection for cheaters from a pool of 10,000 mutants [21]. This pool of mutants was subjected to 20 rounds of growth, development, and spore germination in a mixed population so that cheaters that differentiate into spores with a higher efficiency would become enriched in the evolving population. At the end of the selection, $\operatorname{cht} B$ was one of the mutants that were randomly chosen to be tested for cheating properties. To confirm that $\operatorname{chtB}$ really increased its frequency during the selection, we used quantitative PCR (Q-PCR) to obtain information about the abundance of the chtB allele. We extracted genomic DNA from the entire population after the $1^{\text {st }}, 10^{\text {th }}$, and $20^{\text {th }}$ generations of the selection and used gene-specific primers to quantify the $\operatorname{cht} B$ allele. The mutant $\operatorname{cht} B$ increased 7.4 fold at the $10^{\text {th }}$ generation and 26.4 fold at the $20^{\text {th }}$ (Figure 1), thus supporting the hypothesis that this cheater increased in frequency during the selection.

\section{The cht $B$ gene}

The mutant $\operatorname{cht} B$ was generated by insertional mutation of the pBSR1 plasmid [29] in chromosome 5 at position 


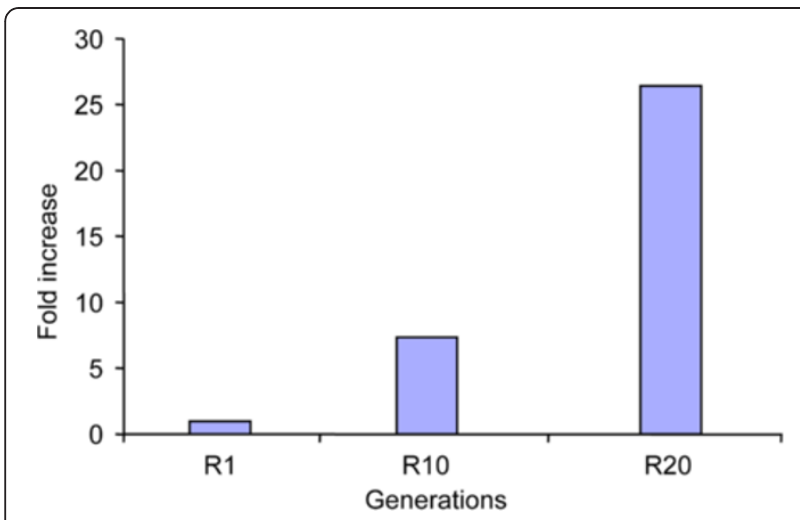

Figure 1 The chtB mutant increases in frequency during the selection. Q-PCR using DNA from the entire population at the $1^{\text {st }}$, $10^{\text {th }}$ and $20^{\text {th }}$ generation (R1, R10 and R20) and using primers specific to the chtB allele, shows that the mutant $c h t B$ increased 26.4 fold by the end of the selection.

4377789 towards the 3 ' end of the ORF of the gene DDB_G0290617 (Figure 2). The predicted protein has not been studied before and it consists of a FNIP repeat (named FNIP after the pattern of a conserved motif found only in $D$. discoideum). We named the gene chtB because its social behavior resembles the previously described chtA mutant [19]. To verify that the insertion was responsible for the mutant phenotype, the mutation was recapitulated by homologous recombination in the AX4 genetic background using the rescued plasmid as a knockout vector [30]. We confirmed the mutation by Southern blot hybridization using a gene-specific probe and tested the strain for cheating.

RT-PCR analysis showed that the parental strain AX4 expressed the chtB mRNA at 0 hours of development and mRNA abundance was greatly increased at 4-24 hours (Figure 3). In the mutant cells, chtB mRNA was not expressed at any time.

\section{The chtB mutant cheats on the parental strain}

To be defined as a cheater, the mutant $\operatorname{cht} B$ must produce significantly more than $50 \%$ of the spores in a pairwise mixing experiment with the parental strain, and this was the case. When mixed at equal proportions with AX4, chtB differentiated $59.9 \pm 3.3 \%$ of the total number of spores. This result differed significantly from the control chimera between AX4 and AX4 [act15/GFP] $(\mathrm{p}<.0001, \mathrm{~T}$-test; Figure 4).

\section{Analysis of fitness cost associated with cheating chtB has no overt morphological defects}

To test whether $\operatorname{cht} B$ shows any morphological difference relative to its ancestor, we observed cells of both strains at different stages of development. In both parent and knockout, we observed loose aggregates at about 10 hours, tight aggregates at 12 hours, fingers at 16 hours and Mexican hats at 20 hours. Between 20 and 24 hours both strains culminated, leading to the formation of well-proportioned fruiting bodies consisting of stalks cells and spores (Figure 5). We saw no noticeable differences between the phenotypes of AX4 and $\operatorname{chtB}$ developed on filters.

\section{cht $B$ differentiates a similar number of spores than $A X 4$ in a pure population}

A fitness cost for a cheater could be manifested as reduced sporulation when developing in a pure population. To test that possibility we developed $\operatorname{cht} B$ cells in a pure population or mixed with AX4 cells. The results (see Additional file 1: Figure S1) show that the sporulation efficiency of chtB $(83.11 \pm 4.69 \%, \mathrm{n}=10)$ is not significantly different from AX4 $(71.53 \pm 5.82 \%, \mathrm{n}=10$, $\mathrm{t}$-test $\mathrm{p}<0.14)$, suggesting that the mutation does not have a sporulation-related fitness cost. The chimera sporulation efficiency was similar to both pure populations $(84.16 \pm 7.26 \%, \mathrm{n}=10$, t-test $\mathrm{p}=0.19$ vs. $\mathrm{AX} 4, \mathrm{p}=0.90$ vs. $\operatorname{cht} B)$.

\section{chtB spores are viable}

We also tested whether a fitness cost may be associated with the spore germination efficiency. Our results show that $\operatorname{cht} B$ was able to germinate a number of spores (72.3 $\pm 16.2 \%)$ comparable to AX4 $(75.5 \pm 15.1 \%$, t-test, $\mathrm{p}=0.08, \mathrm{n}=6$ ). This result indicates that $\operatorname{cht} B$ does not produce fewer viable spores than its parent (Additional file 2: Figure S2).

\section{chtB grows faster in liquid medium}

To compare the growth rates of the $\operatorname{cht} B$ mutant and its ancestor, we grew cultures of $\operatorname{chtB}$ and $\mathrm{AX} 4$ in liquid media starting at a cell density of $1 \times 10^{5}$ cells $/ \mathrm{ml}$. chtB reached log phase after about 40 hours, while AX4 took about 10 hours longer. When in logarithmic phase, $\operatorname{cht} B$ cells showed a doubling time of $7.6 \pm 0.7$ hours (Figure 6) while AX4 cells showed a doubling time of $10.3 \pm 1.5$ hours ( $\mathrm{t}$-test, $\mathrm{p}<0.05, \mathrm{n}=3$ ), showing that $\operatorname{cht} B$ has a faster doubling time than AX4 in liquid medium.

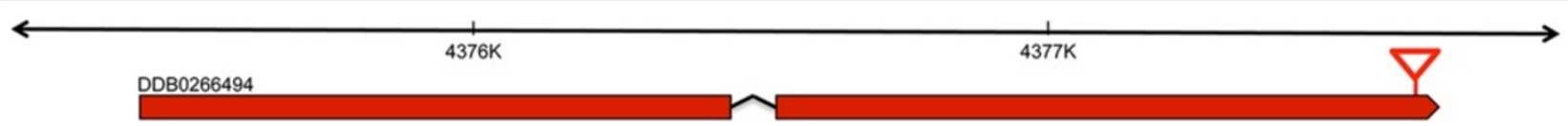

Figure 2 The chtB gene is located on the chromosome 5. The gene contains one short intron (thin black line) and two exons (thick red lines) as indicated in the gene model. The red triangle indicates the position of the insertional mutation generated by REMI. 

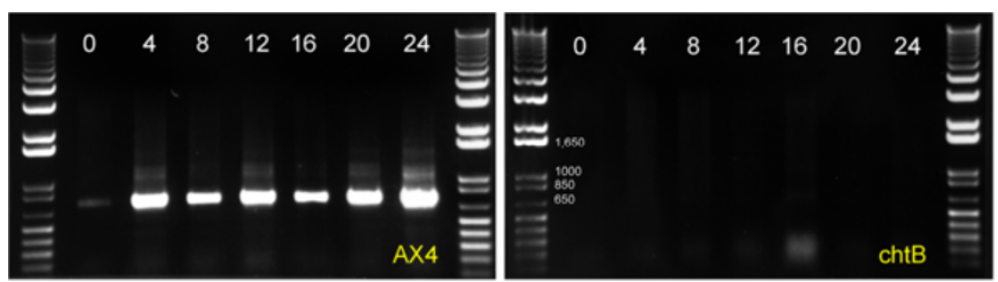

Figure 3 The cht $B$ gene is expressed during development and is completely silent in our mutant. RT-PCR reaction using RNA extracted during a time course (time points indicated in hours) shows that the chtB mRNA is observed only in AX4 during development. No mRNA is detected in the mutant chtB.

\section{Alteration of cell type proportioning as cheating mechanism}

We assessed cell-type proportioning by measuring betagalactosidase activity in cells that express the marker under the promoters of either $\cot B$ [31] (a prespore marker) or ecmA [32] (a prestalk marker). We measured the overall enzyme activity in the population using an ONPGassay and the number of cells of each type using X-gal staining as described [33]. We compared the level of lacZ expression in chimerae between the reporter strains and AX4 or $\operatorname{cht} B$ to determine the effect of $\operatorname{cht} B$ on prespore and prestalk differentiation in the AX4 victim.

\section{Prespore differentiation}

ONPG analysis of AX4 [ $\operatorname{cotB} / / a c Z]$ showed that $\cot B$ is not expressed until 12 hours. Then it starts increasing and reaches saturation at 16 hours (Figure 7). If AX4 [cotB/lac Z] cells were mixed at a 1:1 ratio with AX4 cells that do not express lac $Z$, the level of $\beta$-galactosidase activity is about half of that produced by $\mathrm{AX} 4[\cot B / \operatorname{lac} Z]$

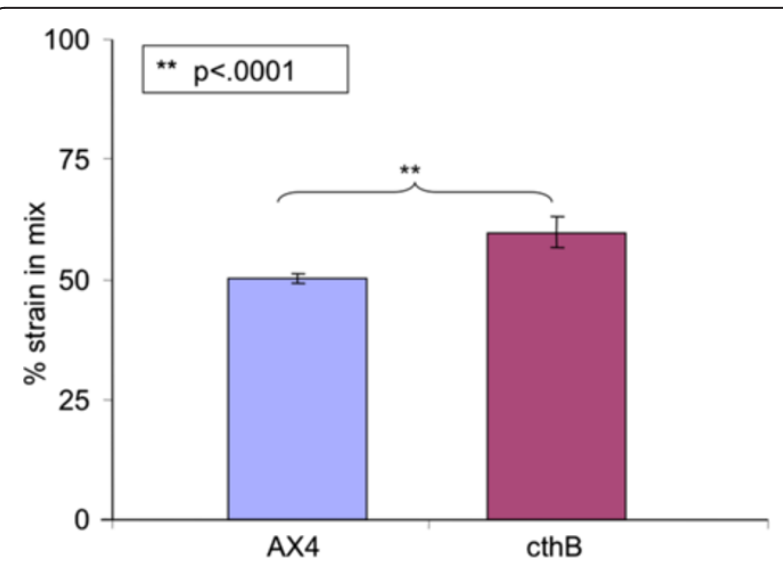

Figure 4 The chtB mutant cheats on $A X 4$. When mixed with the parental strain AX4 [act15/GFP], chtB differentiates 59.9 $\pm 3.3 \%(n=22)$ of the total spores. Control AX4 cells mixed with AX4 [act15/GFP] cells differentiate $50.1 \pm 1.0 \%(n=27)$ of the total number of spores. The $c h t B$ strain differentiates a significantly higher number of spores than the parental strain (Two tailed t-test, $p<.0001$. Bars represent standard errors). alone. When AX4 $[\cot B / \operatorname{lac} Z]$ cells were mixed at the same ratio with chtB cells, the $\beta$-galactosidase activity was significantly lower than in the mix with AX4 (16, 20 and 24 hour time points, $t$-test, $\mathrm{p}<0.05, \mathrm{n}=3$ ). These results show that in chimeras $c h t B$ is able to reduce the expression of $\cot B$ in the wild type cells and that AX4 cells are forced to form fewer prespore-cells than their fair share.

\section{Prestalk differentiation}

To test whether the presence of $\operatorname{chtB}$ cells in chimeras affects prestalk cell formation in the victim, we performed a similar analysis using the strain AX4[ecmA/ lac $Z$ ] alone and in pairwise mixes with AX4 and $\operatorname{chtB}$ (Figure 8). In this case, no significant differences were seen in the $\beta$-galactosidase activity when $\mathrm{AX} 4[\mathrm{ecm} A$ / lacZ] cells are mixed with AX4 or with $\operatorname{chtB}$. We conclude that the presence of $\operatorname{ch} B$ cells in chimeras does not influence the expression of the prestalk marker ecmA in the wild type cells.

\section{Developmental cell fate}

The results obtained with ONPG analysis show that the presence of chtB cells in a mix with $\mathrm{AX} 4$ reduces the promoter activity of the pre-spore gene cotB. This observation could be due to reduced $\cot B$ expression in all the wild type prespore cells, or to a reduction in the number of prespore cells in the wild type. We addressed this issue by counting the number of cells that expressed the marker gene. When AX4 [cotB/lacZ] were mixed in equal proportions with chtB (Figure 9A) they produced a significantly lower percentage of stained cells than when mixed with AX4 (for 16 and 20 hour time points, t-test, $\mathrm{p}<0.05, \mathrm{n}=3$ ). Therefore we conclude that, in chimera with wild type, chtB forces the parental cells to reduce the proportion of prespore cells and, as a consequence, to produce fewer spores. When the same test was performed using the AX4 [ecmA/lacZ] strain (Figure 9B), there was no difference between the number of stained cells observed in mixes of AX4[ecmA/lacZ] with AX4 or chtB (for 16, 20 and 24 hours time points, t-test, $\mathrm{p}>0.26$, $\mathrm{n}=3$ ). We conclude that the presence of chtB in chimera did not affect the number of prestalk A cells produced by 

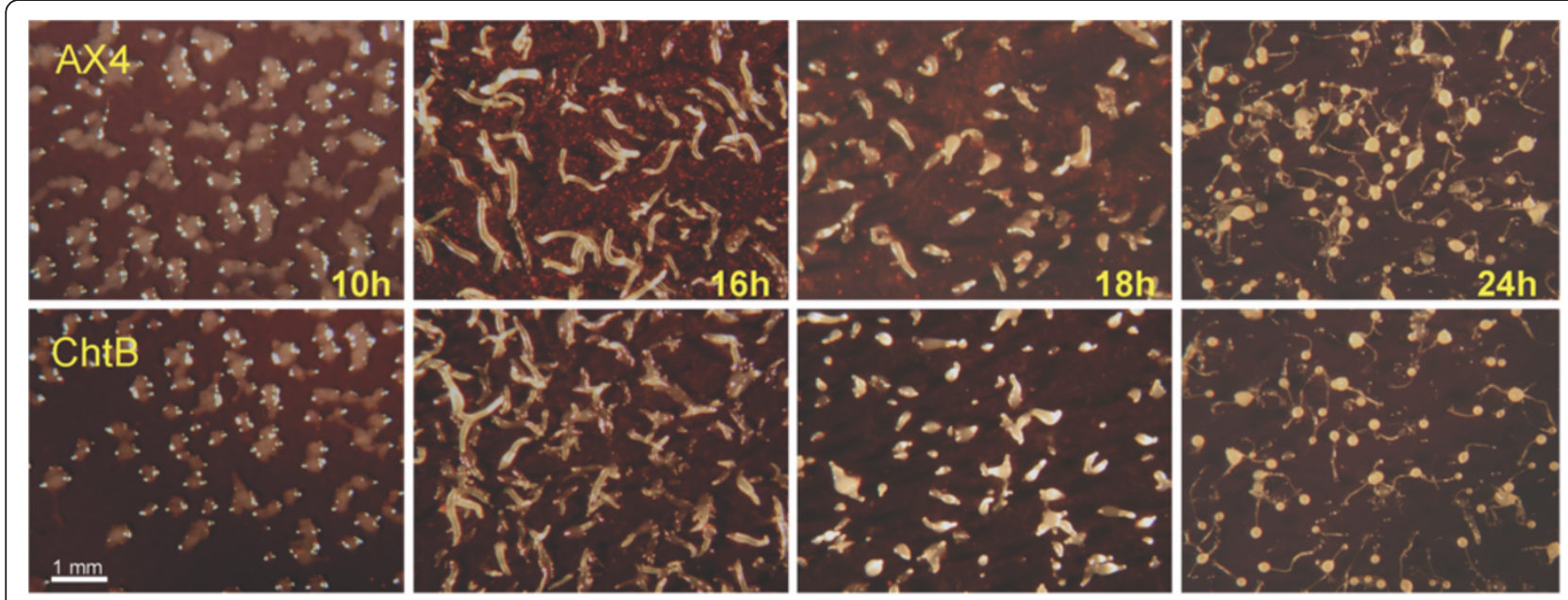

Figure 5 Developmental morphologies of AX4 and chtB. We grew the cells in axenic medium and developed them separately, as indicated, on nitrocellulose filters. We photographed the cells from above at the indicated times (bar $=1 \mathrm{~mm}$ ).

the victim strain, but could have made them become prestalk B (pstB) cells, which normally produces the basal disc of the fruiting body, or pstO cells, which occupy the rear half of the prestalk region.

\section{Discussion}

We isolated and characterized a mutant called $\operatorname{cht} B$ that cheats without overt fitness costs. $\operatorname{ch} t B$ was isolated after a genetic selection for cheaters that were able to form fruiting bodies clonally [21].

The mechanism by which $\operatorname{cht} B$ cheats in chimeras is novel. $\operatorname{cht} B$ reduced the expression of the prespore marker $\cot B$ in the wild type population as a consequence of the wild type strain forming fewer prespore cells than it does in control mixtures. One might expect then that these missing wild type prespore cells end up making

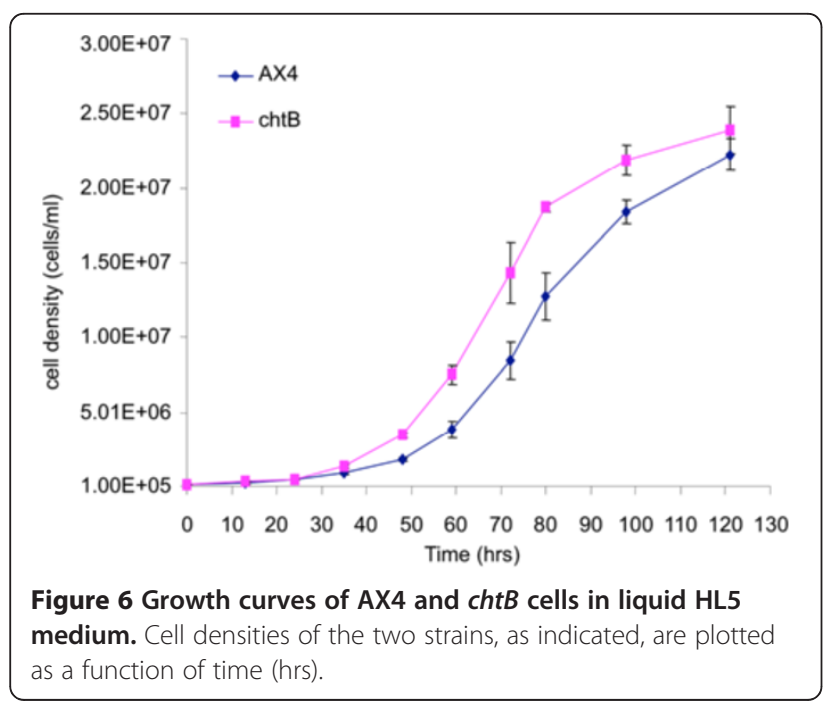

stalk, but we found no evidence for this; $\operatorname{chtB}$ does not alter the wild type expression of the prestalk marker ecmA. It is therefore unclear what happens to the wild type cells that would have produced spores.

To test whether the $\operatorname{cht} B$ mutation was associated with fitness costs, we tested the strain's growth, developmental morphology, sporulation and germination efficiency and found no adverse effects compared to the ancestor AX4. Indeed there was some evidence of better performance by the mutant. The chtB mutant grows faster than the wild type in liquid medium. This finding cannot account for the increase in frequency of $\operatorname{cht} B$ during the original selection, because the selection was performed on agar plates, where $\operatorname{cht} B$ does not have a growth advantage [21].

The behavior of the mutant raises both mechanistic and evolutionary questions. On the mechanistic side, we begin by asking whether its higher representation in spores is due to either fixed or facultative allocation strategies [34]. In the fixed allocation strategy, the cheater produces more spores than the loser when each are grown as pure clones. In this case, the cheater has not changed its behavior in chimera; its solitary strategy carried over to the chimeric setting gives it an advantage. In the facultative allocation strategy, the cheater produces more spores in chimeras than expected from its solitary production. The spore production of $\operatorname{cht} B$ is not significantly higher than that of AX4, suggesting it is a facultative cheater. However the point estimate is higher, so it is worth considering whether, if that non-significant difference were real, it could explain cheating as a fixed strategy. In fact it cannot, as the 59.9\% representation observed in chimeras is significantly more than the expected fixed allocation of $54.0 \%$ (calculated from $\operatorname{cht} B$ 


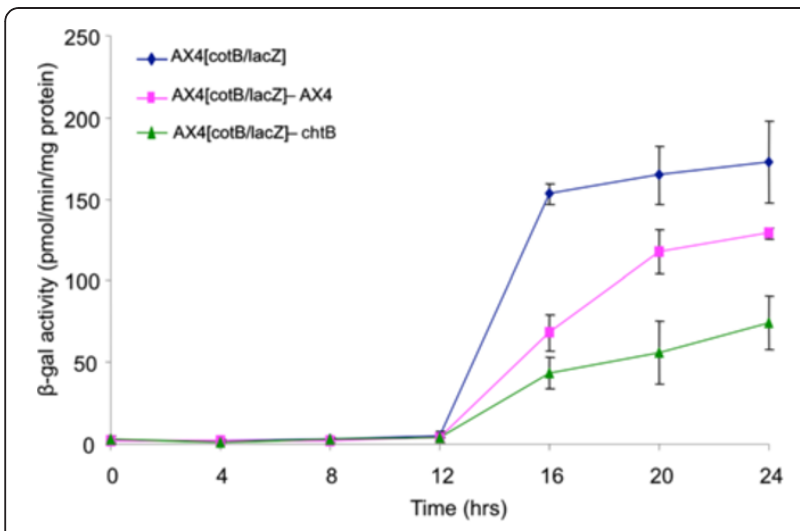

Figure 7 ONPG analysis of AX4 cells expressing the lac $Z$ gene under the prespore promoter $\cot B$. Cells were developed alone or mixed at a 1:1 ratio with $A X 4$ and $c h t B$ cells. Developmental time points (hours) are represented on the $x$-axis and beta-galactosidase activity on the $y$-axis. When $A X 4[\cot B / / a c Z]$ are mixed with $c h t B$ cells, the $\beta$-galactosidase activity is lower than when mixed with AX4 $(16,20$ and 24 hour time points, t-test, $p<0.05, n=3)$.

on its own divided by the sum of $\operatorname{chtB}$ on its own and wildtype on its own, or $83.1 /(71.5+83.1))$. Thus $\operatorname{cht} B$ appears to be a facultative cheater, indicating that an additional cheating mechanism is at play besides fixed higher spore production. Several wild clones of Dictyostelium discoideum [17] and many laboratory mutants $[21,22]$ are also cheaters that do not exhibit overt phenotypic abnormalities, but the previous studies did not explore possible costs that might be associated with the cheating behavior. Cheater strains in a population can be viewed as parasites since they use common resources without paying the cost, which could lead to the collapse of the entire social machinery. Several mechanisms have been suggested to explain why cheaters do not take over

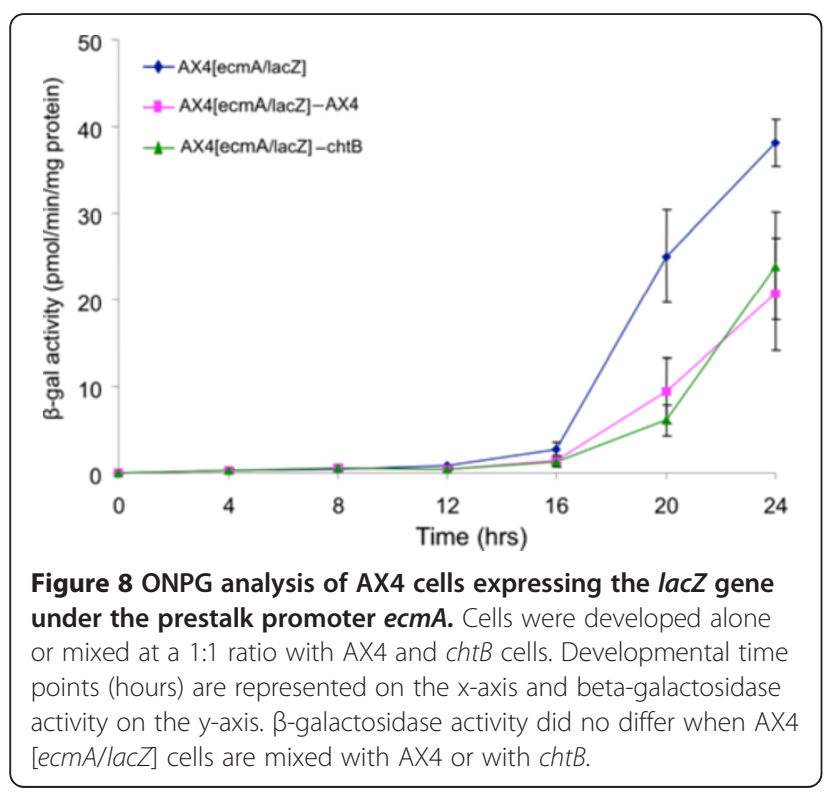

the entire population [35]. High relatedness is an important control of cheaters, because it means that like groups with like, so cheaters have reduced opportunity to exploit cooperators [36,37]. This explanation does not seem to apply to $\operatorname{cht} B$ because it does at least as well as wild type even when alone, so it would appear to be favored even at high relatedness, with an added boost from cheating in any chimeric mixtures.

With or without high relatedness, disadvantageous pleiotropic effects can also keep a mutant from spreading [27]. We detected no pleiotropic disadvantages of chtB. However, there are two important caveats. First, all the cheating experiments reported so far were performed in the laboratory under controlled environments. In the wild, however, factors like temperature, $\mathrm{pH}$, and moisture could influence both cheating efficiency and pleiotropic effects. The $\operatorname{cht} B$ knockout behaves as a cheater under the conditions that we have used, but it may not be able to cheat in nature. Likewise, inactivation of chtB had no apparent adverse consequences in the laboratory, but it must have a cost that would limit its propagation in nature, or the gene would have been lost. Second, selective forces too small to effectively be detected in the laboratory could still be important in nature. One hypothesis that combines these two caveats is that $\operatorname{cht} B$ might suffer from reduced dispersal from shorter stalks. If cht $B$ produces more spores, it may produce shorter stalks. We did not attempt stalk measurements because they are far less accurate and more variable than spore measurements. Shorter stalks might reduce dispersal, presumably by animal vectors. Another possibility is that the mechanism by which $\operatorname{cht} B$ knockouts achieve their success in chimera involves earlier fruiting. If this is the case, it could be that this is normally a disadvantage, keeping the mutant from spreading.

\section{Conclusion}

In this study we describe a novel mechanism by which a $D$. discoideum cheater exploits parental strain cells by inhibiting them from producing spores. One way to understand how cooperative behaviours have evolved and are maintained is to identify the mechanisms cheaters use to exploit such cooperation. Moreover, for the first time we concluded that under our experimental conditions there are no fitness costs associated with the cheater trait investigated, unlike the disadvantageous pleiotropic effects that are suggested mechanisms preventing cheaters from spreading in a population.

\section{Methods}

\section{Strains and growth conditions}

The Dictyostelium discoideum strains used were the axenic strain AX4 [38], AX4 [actin15/GFP], and the REMI mutant chtB [21]. Cells were grown in suspension 

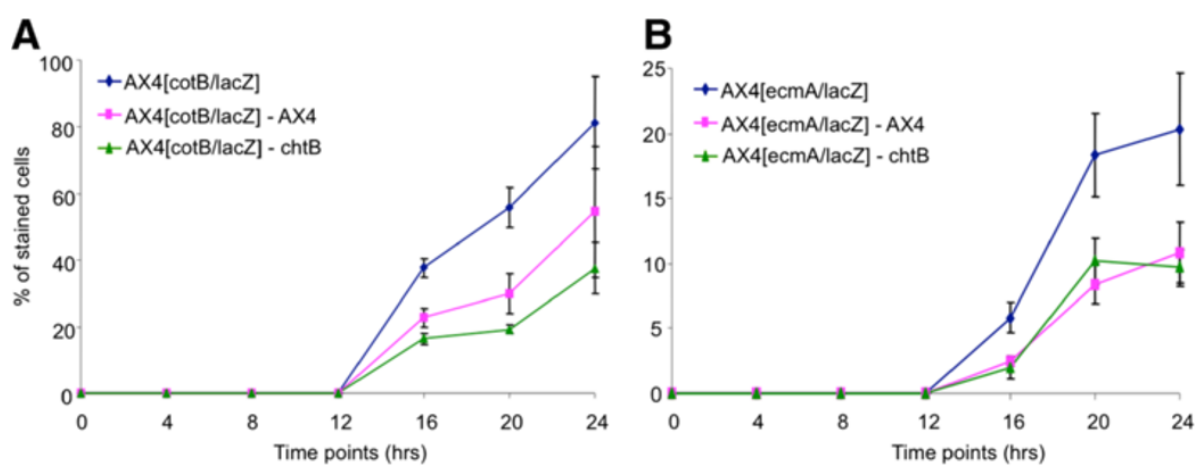

Figure $\mathbf{9}$ Changes in the proportion of prespore cells but not in prestalk cells. (A) Cells expressing lacZ under the $\cot B$ promoter or (B) under the ecmA promoter were developed alone or mixed with AX4 or chtB in a 1:1 ratio. Developmental time points (hours) are represented on the $x$-axis and percentage of stained cells on the $y$-axis. AX4[cotB/lacZ] mixed with chtB at the 16 and 20 hours time point, shows a significantly lower percentage of stained cells than when mixed with $A X 4$ (for the 16 and 20 hours time points, t-test, $p<0.05, n=3$ ). AX4[ecmA/lacZ] mixed with $c h t B$ does not show a significant difference in the percentage of stained cells than when mixed with AX4. (For 16, 20 and 24 hour time points, t-test, $p>0.26, n=3)$.

in HL-5 medium or on SM agar plates in association with Klebsiella aerogenes [39]. HL-5 was supplemented with the antibiotics G418 or Blasticidin S (both at $5 \mu \mathrm{g} / \mathrm{ml}$ ), as required.

Increase in frequency of the cht $B$ gene during the screen Quantitative PCR was performed using the DNA Opticon ${ }^{\circledR}$ Engine system BIO-RAD [40]. As template for the reaction we used genomic DNA extracted from the $1^{\text {st }}, 10^{\text {th }}$ and $20^{\text {th }}$ round of selection. Specific chtB primers were used to obtain amplification. IG7 (a constitutively expressed gene) was used as the loading control. SYBR Green was used as the dsDNA fluorescent dye.

\section{RNA extraction}

AX4 and chtB cells were plated on two black filters each $\left(5 \times 10^{7}\right.$ cells/filter) and the entire populations were collected at different developmental time points. We extracted RNA using the TRIzol reagent (Invitrogen) according to the manufacturer's recommended procedures and dissolved it in $100 \mu \mathrm{l}$ of $1 \mathrm{X}$ MOPS buffer [41].

\section{chtB gene expression}

Total RNA was reverse transcribed using SuperScript ${ }^{\mathrm{TM}}$ II Reverse Transcriptase kit (Invitrogen) and oligo d(T) primers. Q-PCR was performed on the resulting cDNA using $\operatorname{cht} B$ gene-specific primers. The products were resolved by electrophoresis on a $0.8 \%$ agarose gel, stained with ethidium bromide, and observed under UV light.

\section{Cheating assays}

The strain $\operatorname{cht} B$ was tested for cheating behavior in pairwise mixing experiments using the GFP-labeled strain method as described [21].

\section{Developmental morphology}

Wild type and mutant cells were grown in HL5 liquid medium. Once in log phase (between $1 \times 10^{6}$ and $5 \times 10^{6}$ cells $/ \mathrm{ml}$ ), cells were washed twice with $\mathrm{KK} 2$ buffer (16.3mM K $\left.\mathrm{HPO}_{4}, 3.7 \mathrm{mM} \mathrm{K \textrm {H } _ { 2 }} \mathrm{PO}_{4}, \mathrm{pH} 6.2\right)$ and resuspended in PDF $\left(20 \mathrm{mM} \mathrm{KCl}, 5 \mathrm{mM} \mathrm{MgCl}_{2}, 9 \mathrm{mM}\right.$ $\mathrm{K}_{2} \mathrm{HPO}_{4}, 13 \mathrm{mM} \mathrm{KH_{2 }} \mathrm{PO}_{4}, 0.3 \mathrm{mM}$ streptomycin sulfate, $\mathrm{pH}$ 6.4) at a density of $5 \times 10^{7}$ cells $/ \mathrm{ml}$. $1 \mathrm{ml}$ of this cell suspension was deposited on Black nitrocellulose filters [38] and incubated at $22^{\circ} \mathrm{C}$. Pictures were taken every two hours.

\section{Sporulation efficiency}

We plated $5 \times 10^{7}$ cells on a KK2 agar plate both clonally and in 1:1 ratio. After 30 hours the entire contents of the plates were collected and resuspended in $1 \mathrm{ml}$ of KK2 with $0.1 \%$ NP40 so that only spores could survive. To assess spore number, a measured aliquot from each sample was counted with a haematocytometer. The sporulation efficiency was calculated by dividing the number of spores collected at the end of development by the total number of cells plated initially.

\section{Germination efficiency}

Spores were counted and plated out at low density (100-500 per plate) on SM plates with $300 \mu \mathrm{l}$ of Klebsiella aerogenes. After a few days, single plaques were observed in the bacterial lawn, each representing a viable spore. The proportion between the number of plaques observed and the number of the spores plated indicated the germination efficiency.

\section{Doubling time}

Cells were inoculated at a density of $1 \times 10^{5}$ cells $/ \mathrm{ml}$ in $250 \mathrm{ml}$ Pyrex flasks containing $50 \mathrm{ml}$ of HL5. The flasks were shaken at $200 \mathrm{rpm}$ at $22^{\circ} \mathrm{C}$ until the cultures reached 
stationary phase at a density of about $2.5 \times 10^{7}$ cells $/ \mathrm{ml}$. Samples were collected at 12 hour intervals and the cells were counted. Each experiment was repeated three times.

\section{ONPG (ortho-Nitrophenyl- $\beta$-galactoside) analysis and X-gal staining}

The strains used for this analysis were TL1 (AX4 [ $\cot B /$ lacZ]), TL6 (AX4 [ecmA/lacZ]), the chtB mutant and the parental strain AX4. Strains expressing the lac $Z$ gene were grown in the presence of $5 \mu \mathrm{g} / \mathrm{ml} \mathrm{G418}$. Cells were grown in HL5 liquid medium and then plated on black filters as described previously. Each $l a c Z$ strain was plated alone or mixed in 1:1 ratio with AX4 and $\operatorname{chtB}$. AX4 [ $\operatorname{cotB} /$ lac Z] cells were plated in a pure population or mixed at a 1:1 ratio with $\mathrm{AX} 4$ and $\operatorname{cht} B$ on white nitrocellulose filters.

\section{ONPG analysis}

The contents of each filter was washed in KK2 and resuspended in $1 \mathrm{ml}$ of $\mathrm{Z}$ buffer with $1 \%$ Triton in order to extract the protein content. For each sample $5 \mu \mathrm{l}$ were used to determine the protein concentration with a Bradford assay [42]. After normalizing the protein concentration of all the samples, $200 \mu \mathrm{l}$ of the protein extract was added to $200 \mu \mathrm{l}$ of $\mathrm{Z}$ buffer and $200 \mu \mathrm{l}$ of ONPG solution $(4 \mathrm{mg}$ ortho-nitrophenyl-b-D-galactopyranoside in $1 \mathrm{ml}$ of $0.1 \mathrm{M} \mathrm{Z}$ buffer). This mixture was incubated at room temperature and gently shaken until the yellow color developed to the desired intensity. The reaction was stopped by adding 400 $\mu \mathrm{l}$ of $1 \mathrm{M} \mathrm{Na}_{2} \mathrm{CO}_{3}$ and the time recorded. The absorbance of the solution was measured with a spectrophotometer at $420 \mathrm{~nm}$ wavelength. $\beta$-galactosidase activity was calculated using the following formula:

$$
\begin{aligned}
& \text { Specific } \beta \text { - gal.activity } \\
& =\left(\mathrm{A}_{420} \times 2 \times 10^{6}\right) /\left(4700\left(\mathrm{~A}_{420} / \mathrm{mol} \text { ONPG }\right)\right. \\
& \left.\quad \times \text { protein }^{\mathrm{mg}} / \mathrm{ml} \times \operatorname{vol}(\mathrm{ml}) \times \text { time }(\min )\right)
\end{aligned}
$$

\section{X-Gal staining of cells in suspension}

Cells were collected from filters at different time points, resuspended in Pronase buffer $(0.1 \%$ Pronase, $14 \mathrm{mM} \beta$ mercaptoethanol, $150 \mathrm{mM} \mathrm{NaCl}, 50 \mathrm{mM}$ Tris, $\mathrm{pH} 7.0)$ and dissociated by trituration. The cells were fixed stained with X-gal as described [43] and counted under a microscope. For each data point we counted between 150 to 300 cells and determine the percentage of stained cells over the total number.

\section{Additional files}

Additional file 1: Figure S1. Spore production in pure populations and in chimeras. In each experiment we plated $5 \times 10^{7}$ cells on a KK2 plate and allowed them to develop. After 24 hours the contents of the plates were collected, treated with detergent and the spores counted. The sporulation efficiency of $c h t B$ is not significantly different from AX4.

Additional file 2: Figure S2. Germination efficiency assay. Spores of chtB and AX4 strains were plated on SM plates in association with bacteria and the number of viable spores was inferred from the number of plaques formed. $c h t B$ produce a percentage of viable spores comparable to AX4.

\section{Competing interests}

The authors declare that they have no competing interests.

\section{Authors' contributions}

Conceived and designed the experiment and advised on experimental procedure, analysis and writing: LAS, AK, GS, DCQ and JES. Performed the experiments LAS; analyzed the data and wrote the paper: $L A S, A K, G S, D C Q$, and JES. All authors read and approved the final manuscript.

\section{Acknowledgements}

We thank the members of the Kuspa, Queller, Shaulsky and Strassmann labs for friendly support and much advice during the project.

\section{Funding}

This material is partly based upon work supported by the National Science Foundation under Grant Nos. EF0626963, and DEB0918931.

\section{Author details}

'Department of Ecology and Evolutionary Biology, Rice University, Houston, TX 77005, USA. ${ }^{2}$ Department of Molecular and Human Genetics, Baylor College of Medicine, Houston, TX 77030, USA. ${ }^{3}$ Department of Biochemistry and Molecular Biology, Baylor College of Medicine, Houston, TX 77030, USA. ${ }^{4}$ Biology Department, Washington University in St. Louis, St. Louis, MO 63130, USA. ${ }^{5}$ Present address: Department of Zoology, University of Oxford, Oxford OX1 3PS, UK.

Received: 7 June 2012 Accepted: 29 November 2012 Published: 9 January 2013

\section{References}

1. Crespi BJ: The evolution of social behavior in microorganisms. Trends Ecol Evol 2001, 16:178-183.

2. Velicer GJ: Social strife in the microbial world. Trends Microbiol 2003, 11:330-337.

3. West SA, Griffin AS, Garnder A, Diggle SP: Social evolution theory for microorganisms. Nat Rev Microbiol 2006, 4:597-607.

4. West SA, Diggle SP, Buckling A, Gardner A, Griffin AS: The social lives of Microbes. Annu Rev Ecol Evol Syst 2007, 38:53-77.

5. Foster KR, Parkinson $\mathrm{K}$, Thompson CR: What can microbial genetics teach sociobiology? Trends Genet 2007, 23:74-80.

6. Maynard Smith J, Szathmáry E: The Major Transitions in Evolution. Oxford: Freeman; 1995.

7. Buss LW: The Evolution of Individuality. Princeton: Princeton Univ Press; 1987.

8. Hamilton WD: The genetical evolution of social behavior. J Theor Biol 1964, 7:1-152.

9. Hardin G: The tragedy of the commons. Science 1968, 162:1243-1248.

10. Griffin AS, West SA, Buckling A: Cooperation and competition in pathogenic bacteria. Nature 2004, 430:1024-1027.

11. Velicer GJ, Kroos L, Lenski RE: Loss of social behaviors by Myxococcus xanthus during evolution in an unstructured habitat. Proc Natl Acad Sci USA 1998, 95:12376-12380.

12. Velicer GJ, Kroos L, Lenski RE: Developmental cheating in the social bacterium Myxococcus xanthus. Nature 2000, 404:598-601.

13. Bonner JT: The cellular slime molds. 2nd edition. Princeton, NJ: Princeton University Press; 1967.

14. Bonner JT, Clarke WW Jr, Neely CL Jr, Slifkin MK: The orientation to light and the extremely sensitive orientation to temperature gradients in the slime mold Dictyostelium discoideum. J Cell Physio/ 1950, 36:149-158.

15. Newell PC, Telser A, Sussman M: Alternative developmental pathways determined by environmental conditions in the cellular slime mold dictyostelium discoideum. Am Soc Microbiol 1969, 100:763-768.

16. Raper KB: The Dictyostelids. Princeton, NJ: Princeton University Press; 1984. 
17. Strassmann JE, Zhu Y, Queller DC: Altruism and social cheating in the social amoeba Dictyostelium discoideum. Nature 2000, 408:965-967.

18. Buss LW: Somatic cell parasitism and the evolution of somatic tissue compatibility. Proc Natl Acad Sci USA 1982, 79:5337-5341.

19. Ennis HL, Dao DN, Pukatzki SU, Kessin RH: Dictyostelium amoebae lacking an F-box protein form spores rather than stalk in chimeras with wild type. Proc Natl Acad Sci USA 2000, 97:3292-3297.

20. Filosa MF: Heterocytosis in cellular slime molds. Am Nat 1962, 96:79-91.

21. Santorelli LA, Thompson CRL, Villegas E, Svetz J, Dinh C, Parikh A, Sucgang R, Kuspa A, Strassmann JE, Queller DC, Shaulsky G: Facultative cheater mutants reveal the genetic complexity of cooperation in social amoebae. Nature 2008, 451:1107-1110.

22. Khare A, Shaulsky G: Cheating by exploitation of development prestalk patterning in Dictyostelium discoideum. PloS Gen 2010, 6:1-12.

23. Shaulsky G, Kessin RH: The cold war of the social amoebae. Curr Biol 2007, 17:R684-R692.

24. Kuzdzal-Fick JJ, Queller DC, Strassmann JE: An invitation to die: initiators of sociality in a social amoeba become selfish spores. Biol Lett 2010, 6:800-802.

25. Nizak C, Fitzhenry RJ, Kessin RH: Exploitation of other social amoebae by dictyostelium caveatum. PLoS One 2007, 2(2):e212.

26. Hagiwara H, Someya A: Killer activity observed in Dictyostelid cellular slime molds. Bull. Nat. Sci. Mus. Tokyo 1992, 18:17-22.

27. Foster KR, Shaulsky G, Strassmann JE, Queller DC, Thompson CRL: Pleiotropy as a mechanism to stabilize cooperation. Nature 2004, 431:693-696.

28. Ponte E, Bracoo E, Faix J, Bozzaro S: Detection of subtle phenotypes: the case of the cell adhesion molecule csA in Dictyostelium. Proc Natl Acad Sci USA 1998, 95:9360-9365.

29. Shaulsky G, Escalante R, Loomis WF: Developmental signal transduction pathways uncovered by genetic suppressors. Proc Natl Acad Sci USA 1996, 93:15260-15265.

30. Kuspa A, Loomis WF: Tagging developmental genes in Dictyostelium by restriction enzyme-mediated integration of plasmid DNA. Proc Natl Acad Sci USA 1992, 89:8803-8807.

31. Fosnaugh K, Fuller D, Loomis WF: Structural roles of the spore coat proteins in Dictyostelium discoideum. Dev Biol 1994, 166:823-825.

32. Morrison A, Blanton RL, Grimson M, et al: Disruption of the gene encoding the EcmA, extracellular matrix protein of Dictyostelium alters slug morphology. Dev Biol 1994, 163:457-466.

33. Shaulsky G, Kuspa A, Loomis WF: A multidrug resistance transporter/serine protease gene is required for prestalk specialization in Dictyostelium. Genes Dev 1995, 9:1111-1122.

34. Buttery NJ, Rozen DE, Wolf JB, Thompson CRL: Quantification of social behavior in D. discoideum reveals complex fixed and facultative strategies. Cur. Biol. 2009, 19:1373-1377.

35. Strassmann JE, Queller DC: Evolution of cooperation and control of cheating in a social microbe. Proc Natl Acad Sci USA 2012, doi:10.1073/ pnas. 1102451108.

36. Gilbert OG, Foster KR, Mehdiabadi NJ, Strassmann JE, Queller DC: High relatedness maintains multicellular cooperation in a social amoeba by controlling cheater mutants. Proc Natl Acad Sci USA 2007, 104:8913-8917.

37. West SA, Pen I, Griffin AS: Cooperation and competition between relatives. Science 2002, 296:72-75.

38. Knecht DA, Cohen SM, Loomis WF, Lodish HF: Developmental regulation of Dictyostelium discoideum actin gene fusions carried on low-copy and high-copy transformation vectors. Mol Cell Biol 1986, 6:3973-3983.

39. Sussman M: Cultivation and synchronous morphogenesis of Dictyostelium under controlled experimental conditions. Methods Cell Biol 1987, 28:9-29.

40. Heid CA, Stevens J, Livak KJ, Williams PM: Real time quantitative PCR. Genome Res 1996, 6:986-994.

41. Neidhart F, Bloch PL, Smith DF: Culture medium for Enterobacteria. J Bacteriol 1974, 119:736-747.

42. Bradford MM: A rapid and sensitive method for quantitation of microgram quantities of protein utilizing the principle of protein-dyebinding. Anal Biochem 1976, 72:248-254.

43. Shaulsky G, Loomis WF: Cell type regulation in response to expression of ricin A in Dictyostelium. Develop Biol 1993, 160:85-98.

\section{Submit your next manuscript to BioMed Central and take full advantage of:}

- Convenient online submission

- Thorough peer review

- No space constraints or color figure charges

- Immediate publication on acceptance

- Inclusion in PubMed, CAS, Scopus and Google Scholar

- Research which is freely available for redistribution 